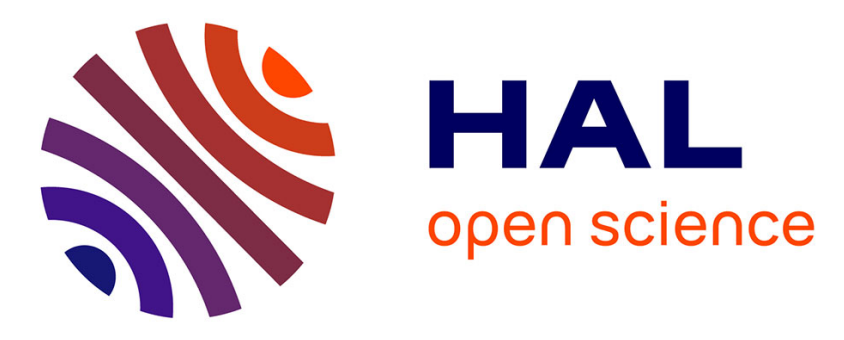

\title{
Experimental and Numerical Study of the Influence of String Mismatch on the Yield of PV Modules Augmented By Static Planar Reflectors
}

Marko Pavlov, Anne Migan-Dubois, Vincent Bourdin, Michel Pons, Martial Haeffelin, Jordi Badosa

\section{To cite this version:}

Marko Pavlov, Anne Migan-Dubois, Vincent Bourdin, Michel Pons, Martial Haeffelin, et al.. Experimental and Numerical Study of the Influence of String Mismatch on the Yield of PV Modules Augmented By Static Planar Reflectors. IEEE Journal of Photovoltaics, 2015, 5 (6), pp.1686. 10.1109/JPHOTOV.2015.2478057 . hal-01231750

\section{HAL Id: hal-01231750}

https://hal-centralesupelec.archives-ouvertes.fr/hal-01231750

Submitted on 20 Nov 2015

HAL is a multi-disciplinary open access archive for the deposit and dissemination of scientific research documents, whether they are published or not. The documents may come from teaching and research institutions in France or abroad, or from public or private research centers.
L'archive ouverte pluridisciplinaire HAL, est destinée au dépôt et à la diffusion de documents scientifiques de niveau recherche, publiés ou non, émanant des établissements d'enseignement et de recherche français ou étrangers, des laboratoires publics ou privés. 


\title{
Experimental and Numerical Study of the Influence of String Mismatch on the Yield of PV Modules Augmented By Static Planar Reflectors
}

\author{
Marko Pavlov, Student Member, IEEE, Anne Migan, Vincent Bourdin, Michel Pons, Martial Haeffelin, \\ and Jordi Badosa
}

\begin{abstract}
Photovoltaic (PV) modules are generally installed by the application of empirical rules aimed at reducing shadows during the periods of high solar irradiation. A traditional installation on a horizontal surface results in largely spaced rows of modules with a relatively low tilt angle. The addition of inter-row reflectors results in more direct and diffuse flux transmitted to the cells. The "Aleph" (Amélioration de l'Efficacité Photovoltaïque) project aims to define clear rules for optimal settings of systems of PV module rows with fixed inter-row planar reflectors in a given location and under a given climate. Two PV technologies are tested for performance with this type of system: amorphous silicon $(a-\mathrm{Si})$ and polycrystalline silicon $(p-\mathrm{Si})$. This work combines experiments on panel behavior in an outdoor environment on the SIRTA (Site Instrumental de Recherche par Télédétection Atmosphérique) meteorology platform and a multiphysics numerical model used to couple all the important physical phenomena and accurately describe the system behavior. The model includes a ray tracing radiation/optics module based on the Monte-Carlo method, as well as an electrical module simulated in SPICE. This work presents the influence of the string mismatch losses, present at periods of heterogeneous illumination, on the yield of PV modules augmented by static planar reflectors.
\end{abstract}

Index Terms-photovoltaic modules, low concentration, planar reflectors, increase of production, multiphysics model, simulation, optimization.

\section{INTRODUCTION}

$\mathbf{T}$ HE Aleph experiment is rooted in the recognition of the constraints on the design of conventional photovoltaic (PV) installations on a horizontal plane, such as rooftop installations and large-scale solar farms installed in the field. In a typical installation, system density, defined here as the ratio between the cell surface and the surface of the field, is limited by the need to minimize shading periods which occur in the morning and evening periods. The resulting system is of a relatively low angle of inclination " $s$ " of the PV modules and an inter-row spacing " $D$ " equal to 4-5 times the module height " $L "$ (see Fig. 1). This arrangement results in the interrow space being illuminated during the period of highest solar

M. Pavlov, V. Bourdin and M. Pons are with the Laboratoire d'Informatique et de Mécanique pour les Sciences de l'Ingénieur (LIMSI), Orsay Cedex, France (e-mail: marko.pavlov@limsi.fr).

M. Pavlov and A. Migan are with the Laboratoire de Génie électrique et électronique de Paris (GeePs), Gif-sur-Yvette Cedex, France (e-mail: anne.migan-dubois@geeps.centralesupelec.fr).

M. Haeffelin and J. Badosa are with the Laboratoire de Météorologie Dynamique (LMD), Palaiseau Cedex, France (e-mail: jordi.badosa@1md.polytechnique.fr).

Manuscript received June, 2015. irradiation (around solar noon). The Aleph project aims to explore the benefit of adding inter-row planar reflectors to increase the system yield.

The use of planar reflectors is an already established technique for increasing the solar flux incident on a collector, and various studies have been performed for estimating the increase in irradiation from a given collector-reflector system geometry [1]-[27]. Ronnelid et al. [20] performed a theoretical study of the planar reflector system. For a latitude of $60^{\circ} \mathrm{N}$ and a specular reflector with a reflectivity of 0.8 , a gain in annual output from $a$-Si PV modules of up to $25 \%$ was predicted. Matsushima et al. [14] explored the benefit of adding booster reflectors by placing the reflector at a $90^{\circ}$ angle with a $c$ Si PV module and varying the inclination of the assembly. With a latitude of about $35^{\circ} \mathrm{N}$ (Tokyo, Japan) and a specular reflector with a reflectivity of 0.95 , a gain of $50 \%$ in produced electricity was estimated. Andrews et al. [3] experimentally tested the PV-booster system over a year. For the latitude of $44^{\circ} \mathrm{N}$ (Kingston, Canada), a specular reflector with a reflectivity of 0.90 and a $c$-Si module, a gain of $45 \%$ of produced energy was observed.

This work presents the influence of the string mismatch losses, present at periods of heterogeneous illumination, on the yield of PV modules equipped by static planar reflectors.

\section{EXPERIMENTAL SETUP}

The experiment is installed in the SIRTA [28] meteorological station in Palaiseau, France, located at $48.71^{\circ} \mathrm{N}, 2.21^{\circ} \mathrm{E}$. It currently consists of three rows of six PV modules. Each row is comprised of modules of two technologies: amorphous silicon $(a-\mathrm{Si})$ and polycrystalline silicon $(p-\mathrm{Si})$.

The modules are inclined with an angle of $s=49^{\circ}$ (roughly equal to the latitude) and the rows are spaced apart with a distance $D / L=3 / 1$ (see Fig. 1), avoiding most shading in the winter. The two rear rows are equipped with planar reflectors consisting of low-cost mirrors of $3 \mathrm{~mm}$ thickness. On September 26, 2014, aluminum foil was installed as reflector on row 3 . The configuration is adjustable and provides space for an additional row of modules and mirrors. The PV modules are orientated as portrait or landscape to allow for a study of the impact of the module orientation on the degree of string mismatch.

The set is instrumented to acquire data continuously from sunrise to sunset. The $I-V$ characteristic is measured using 


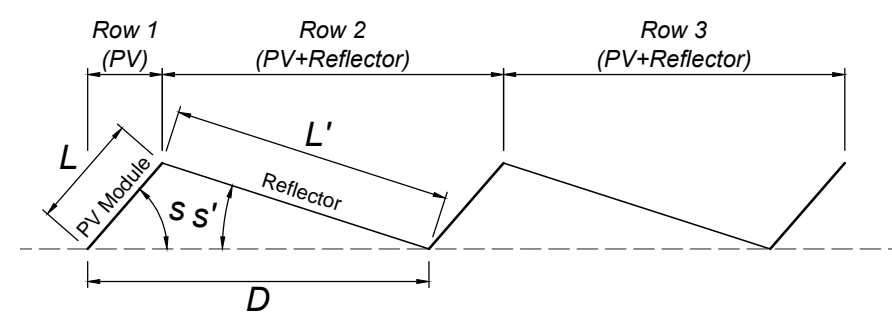

Fig. 1. Schematic of the experiment. PV module rows 2 and 3 are equipped with reflectors, row 1 serves as the control.

a Keithley 2635A SourceMeter, and a Keithley Multiplexers switch 3706A with two communication cards, 3720 and 3721. The operating temperature of the PV modules is measured at the rear of each module using class A platinum probes, Pt-100.

Access to all atmospheric variables measured by SIRTA has been granted, including global, diffuse, and direct irradiances, local albedo, air temperature and humidity, speed and wind direction at various altitudes, and satellite images.

\section{EXPERIMENTAL RESULTS}

The collected data demonstrate the interest of this system. Fig. 2 presents the gain in the daily and monthly produced energy achieved by $p$-Si and $a$-Si PV modules under concentration compared to the control modules. The modules under concentration represented here are situated in the middle of rows 2 and 3, and are therefore not subject to severe edge effects. The monthly gain is highest at spring and fall, and reaches $26 \%$ for $a$-Si modules and $18 \%$ for $p$-Si modules. Comparable gains were observed for two reflector types, ordinary mirror and aluminum foil. The daily gain reaches $35 \%$ at certain periods of the year. Note that higher gains are achieved for $a$-Si compared to $p$-Si modules, owing to different layouts of cells.

As all the modules are measured with the same sourcemeter, simultaneous continuous measurements are not feasible and a time lag exists between the determinations of the $P_{m p p}$ of each module. Therefore, measurements made during periods of highly varying solar irradiation (e.g. during the presence of clouds) may suggest unfavourable ratios of energy production.

Unfavourable monthly ratios of energy production in the winter months, as suggested by Fig. 2, can be largely attributed to the above-mentioned data acquisition limitation when taking measurements during periods of intermittent solar resource. This becomes clear when one notes a rather constant gain in daily produced energy during overcast days (days with high daily average DHI/GHI, shown in grey), and a seemingly variable gain during intermittent days (shown in yellow). A secondary factor contributing to unfavourable ratios of energy production in the winter period is the presence of shadows on reflector-equipped modules during early morning and late evening periods of winter days. This shadow does not appear on the frontal modules used as control, resulting in an apparent loss of energy. However, the shadow effect would be identical for the two systems (PV+Reflector and classical installation) constructed with the same inter-row spacing. For these reasons

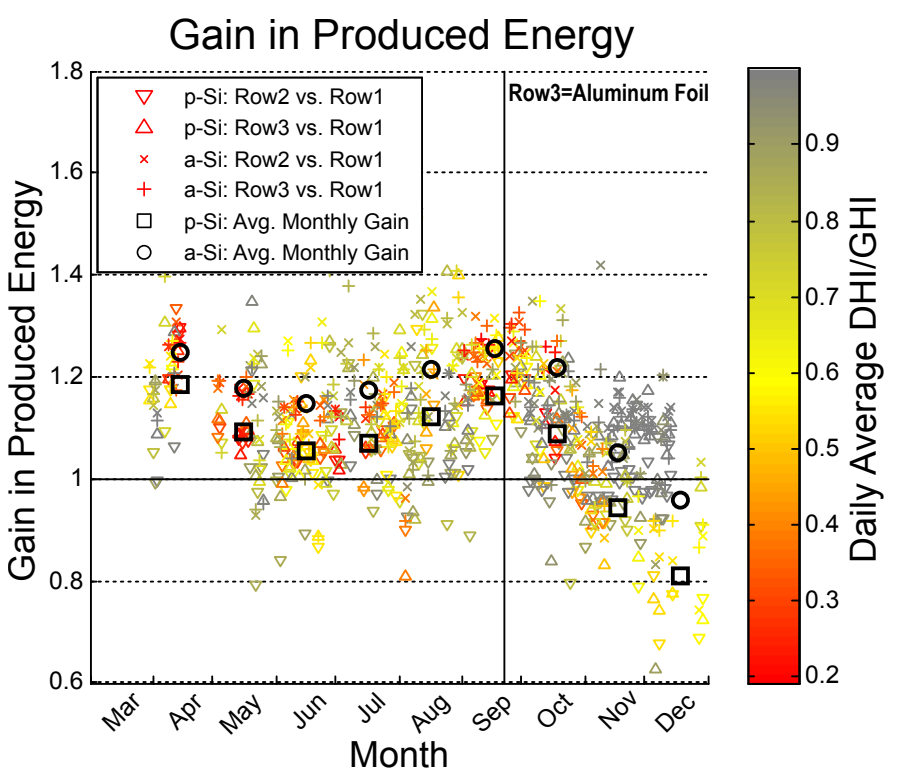

Fig. 2. Experimental data: gain in daily and monthly produced energy resulting from concentration. After September 26, 2014, the third row was equipped with aluminum foil as reflector. Values below 1 are due to isolated spikes of high illumination during the measurement of a particular PV module in an otherwise very cloudy day. The color scale represents the daily ratio of diffuse to global irradiation.

and contrary to what the data suggests, no losses of energy should be expected with the addition of inter-row planar reflectors.

It is interesting to note that the shadow has a different effect on the two technologies, having a greater impact on the performance of $p$-Si modules. This is because the resulting heterogeneous illumination produces a more severe string mismatch effect for the $p$-Si compared to the $a$-Si modules.

\section{NumericAl MOdelLing}

To correctly describe the electricity production of the planar concentrator PV system, it is important to build a multiphysics model integrating all the relevant phenomena, such as the solar resource, the photovoltaic conversion process, as well as the applicable loss mechanisms. Andrews et al. [2] give an excellent overview of the loss mechanisms present in this kind of system, namely angle-of-incidence losses, reflection losses, string mismatch, temperature effects and spectral mismatch.

\section{A. Ray Tracing Module}

To describe the total flux transmitted to the cells, which includes the contribution of the reflector and the optical losses, a ray tracing model was developed in the EDStar environment [29]. The geometry was modelled in 3D using the PBRT framework, commonly used for rendering 3D models. It was described as an inclined reflector surface and an oppositely inclined receiver surface, representing the imaginary PV-cell surface in the plane of the modules encompassing all the modules in the experiment. Reflectance of the reflector as well as the transmittance and reflectance of the PV module front glass were described using the procedure outlined by Hoang 


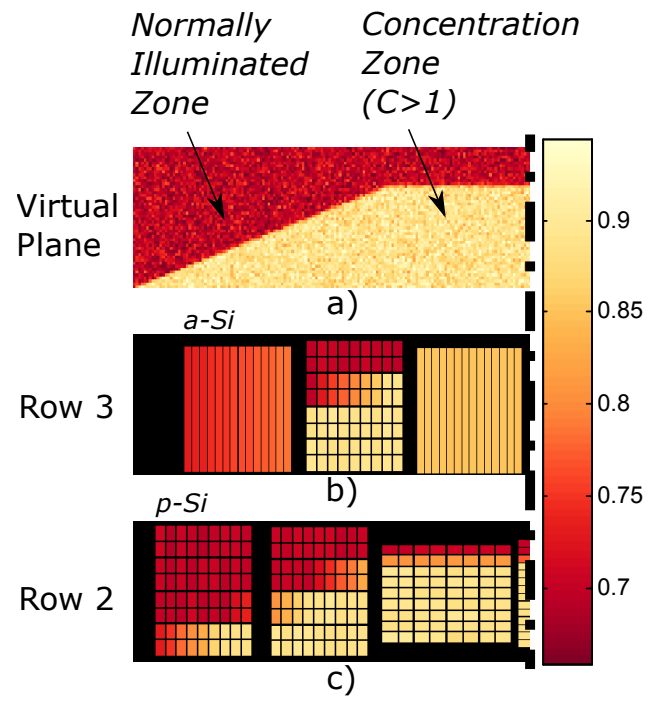

Fig. 3. Concentration-shading-transmission factor, in the plane of the modules (a) and average by cell for PV modules in rows 3 and 2 (b),(c) - October 15, 2014, 13:50 UTC

et al. [30], applying the refractive indices of materials found in the literature [31]. The reflectivity was adjusted to account for the spectral mismatch between the reflected wavelengths and the spectral response of the modules.

To precisely describe the position of the sun relative to the system at any moment, several astronomical variables had to be calculated. Solar declination and the equation of time were defined by the means of empirical formulas as outlined by Bourdin [32], based on the data provided by IMCCE [33]. The corresponding maximum error resulting from using the empirical formulas is $\pm 0.20^{\circ}$ and 16 seconds, respectively. The local hour angle, solar altitude and solar azimuth, were found using the equations derived by Duffie and Beckman [34].

The direct flux was modelled using the "pill-box" sun model, meaning that the surface of the sun, as seen from Earth, was sampled with a uniform probability during the MonteCarlo simulations. The diffuse flux was modelled using the isotropic sky model [35].

Monte-Carlo simulations were run with 10,000,000 histories. This yielded a $2 \mathrm{D}$ distribution of the factor of concentration or shading, present on the imaginary PV-cell surface (see Fig. 3a). Since the angle-dependent transmission through the module front layers is calculated at each history, this factor includes the corresponding losses. The resolution of this distribution was set at $48 \times 288$ "pixels", which is high enough to study the string mismatch effect while resulting in an acceptable standard deviation.

MATLAB was used to transform this 2D distribution into an average concentration by cell, taking as an input the physical arrangement of the modules (see Fig. $3 b$ and $3 c$ ).

\section{B. Electrical Module}

After having calculated both the direct and diffuse flux factors of concentration-shading-transmission by cell, multiplying them by appropriate irradiance values results in the total flux

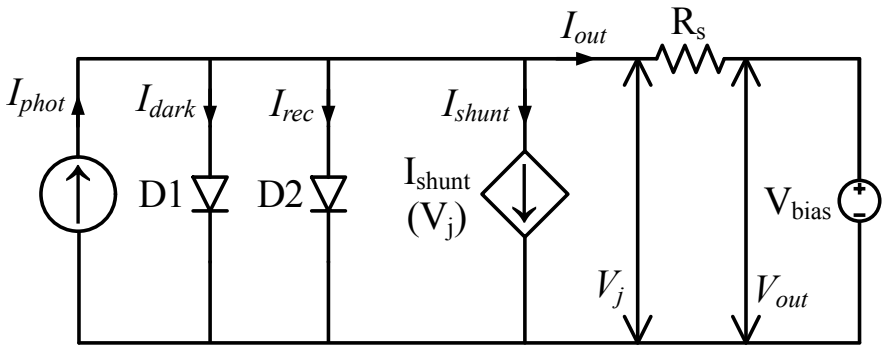

Fig. 4. Schematic of the electrical model of a $p$-Si cell, consisting of a current source, two diodes, a series resistance, and a shunt current term (as described by Bishop [36]).

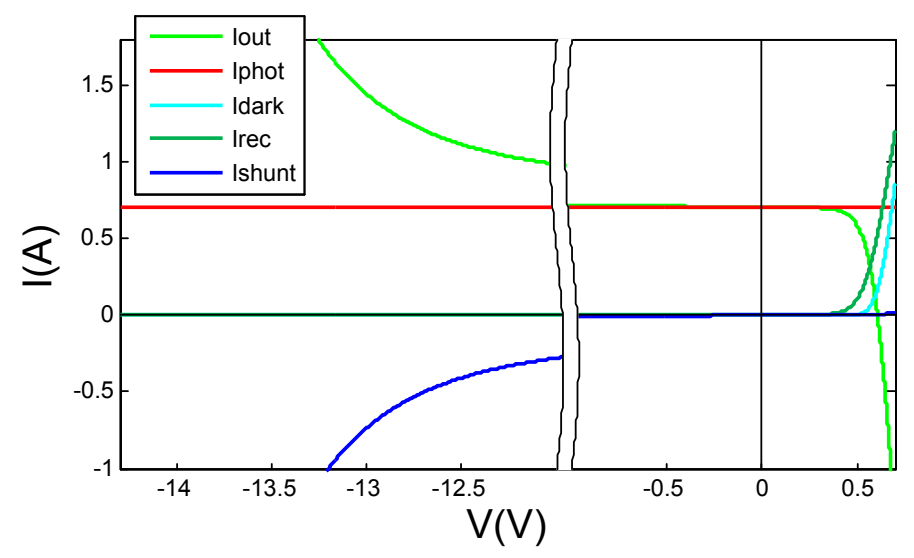

Fig. 5. Current in each component of the $p$-Si cell model as a function of applied voltage. The cell was parametrized according to Table I and subjected to STC conditions.

values transmitted to the cells. The electrical behaviour of the two kinds of modules were modelled in SPICE, starting with developing an equivalent circuit model of a cell of each PV technology.

A $p$-Si cell was modelled using a modified 2-diode equivalent circuit model where the parallel resistance was replaced with a voltage-dependent term describing the avalanche breakdown during reverse bias, as described by Bishop [36] and Silvestre et al. [37]. Figure 4 shows the schematic of the electrical model of a $p$-Si cell.

Figure 5 shows the current in each component of the $p$ $\mathrm{Si}$ cell model as a function of the applied voltage bias. The cell was parametrized using the values shown in Table I, and subjected to STC conditions $\left(1000 \mathrm{~W} / \mathrm{m}^{2}, 25^{\circ} \mathrm{C}\right)$. The breakdown voltage was set to $-15 \mathrm{~V}$, resulting in a rapid increase in the shunt current as the voltage bias approaches $-15 \mathrm{~V}$.

An $a$-Si cell was modelled using a 1-diode model with two additional terms: one to describe the avalanche breakdown (as done for the $p$-Si cell), and a second to describe the recombination in the $i$-layer, as outlined by Merten et al. [38]. Figure 6 shows the schematic of the electrical model of a $a-\mathrm{Si}$ cell.

Figure 7 shows the current in each component of the $a-\mathrm{Si}$ cell model. The cell was parametrized using the values shown in Table I, and subjected to STC conditions. Similarly to the $p$-Si cell, the shunt current increases rapidly as the voltage bias approaches the set breakdown voltage, $-20 \mathrm{~V}$. Note the 


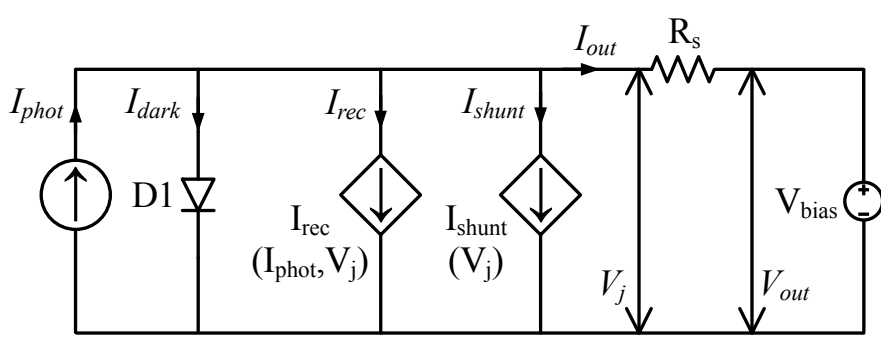

Fig. 6. Schematic of the electrical model of a $a$-Si cell, consisting of a current source, a diode, a series resistance, a recombination current term (as described by Merten et al. [38]), and a shunt current term (as described by Bishop [36].
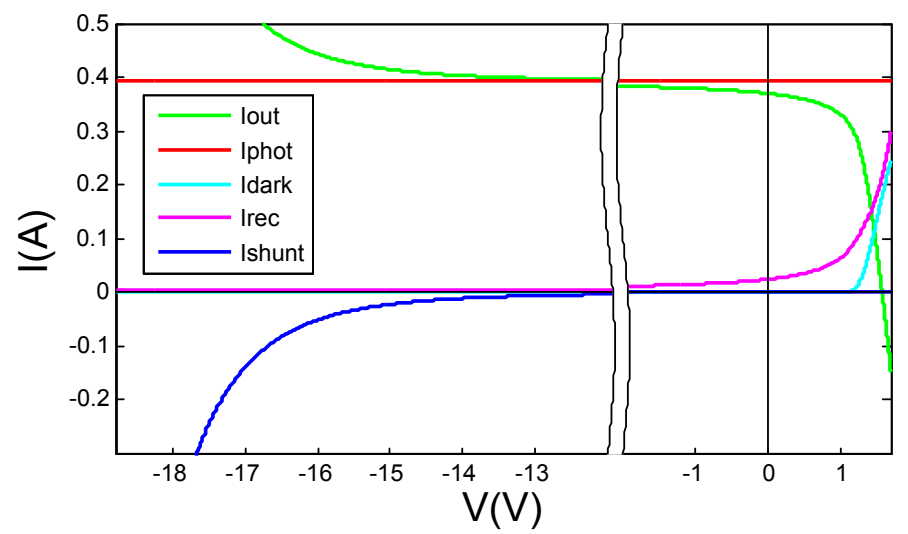

Fig. 7. Current in each component of the $a$-Si cell model as a function of applied voltage. The cell was parametrized according to Table I and subjected to STC conditions.

effect of the $i$-layer recombination term. Compared to the diode equation, it rises more gradually with voltage.

For each technology, the PV modules were modelled by electrically connecting individual cells in series. In the case of $p$-Si, two bypass diodes were added, one across each string. These diodes were parametrized as follows: the saturation current and the emission coefficient were set to $1 \times 10^{-7}$ $A / \mathrm{cm}^{2}$ and 1.00 , respectively. To illustrate the influence of the bypass diodes, the $I-V$ characteristic was simulated for an east edge $p$-Si module at various points throughout the morning period, characterized by different distributions of the concentration-shading-transmission factor (see Fig. 8). To emphasize the mismatch effect, the beam normal and diffuse horizontal irradiances were set to 800 and $0 \mathrm{~W} / \mathrm{m}^{2}$, respectively. The operating temperature was fixed at $70{ }^{\circ} \mathrm{C}$. The simulation was run for August 16, 2014, at: a) 07:55, b) 09:15, c) 10:47, d) 11:08, and e) 11:55 UTC. It can be seen that in forward bias conditions, the influence of the bypass diodes depends on the degree of mismatch, while in reverse bias (around $-0.7 \mathrm{~V}$ ) they result in a rapid increase in current.

The electrical model was calibrated using experimental measurements. The electrical parameters were adjusted through trial and error until the $I-V$ curves measured at several times of the day were reproduced by the model (see Fig. 9 for an example). The obtained electrical parameters are listed in Table I. Figure 9 shows the model behaviour after calibration for an $a$-Si module under concentration, on May 17, 2014 at 10:39 UTC.

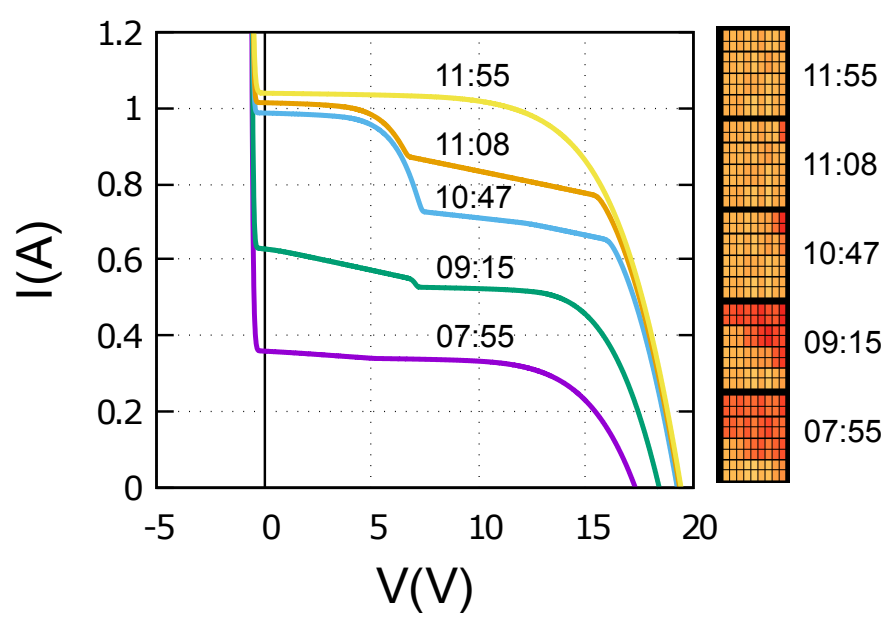

Fig. 8. Simulated $I-V$ characteristic of an edge $p$-Si module, equipped with two bypass diodes, resulting from different distributions of the concentration zone and hence degrees of string mismatch. The bypass diodes are active in mismatch conditions, as well as in reverse bias.

TABLE I

ELECTRIC PARAMETERS OF $a$-Si AND $p$-Si CELlS

\begin{tabular}{ccc}
\hline Parameter & $\boldsymbol{p}$-Si & $\boldsymbol{a}$-Si \\
\hline Area $\left(\mathrm{cm}^{2}\right)$ & 22.0 & 65.9 \\
$J_{0}\left(A / \mathrm{cm}^{2}\right)$ & $5.00 \times 10^{-13}$ & $5.00 \times 10^{-19}$ \\
$J_{02}\left(A / \mathrm{cm}^{2}\right)$ & $2.30 \times 10^{-7}$ & - \\
$J_{S C, S T C}\left(A / \mathrm{cm}^{2}\right)$ & $3.80 \times 10^{-2}$ & $8.20 \times 10^{-2}$ \\
$R s\left(\Omega . \mathrm{cm}^{2}\right)$ & 0.55 & 26.36 \\
$R s h\left(\Omega . \mathrm{cm}^{2}\right)$ & 1650 & 6590 \\
$\alpha_{I s c}\left(1 /{ }^{\circ} \mathrm{C}\right)$ & $6.00 \times 10^{-4}$ & $1.20 \times 10^{-3}$ \\
$n_{1}$ & 1.00 & 1.60 \\
$n_{2}$ & 2.00 & - \\
$a$ & $2.00 \times 10^{-3}$ & 0.10 \\
$m$ & 3.70 & 3.70 \\
$V_{b r}(V)$ & -15.0 & -20.0 \\
$d_{i}(\mathrm{~cm})$ & - & $3.50 \times 10^{-5}$ \\
$\mu \tau_{e f f}(\mathrm{~cm} / \mathrm{V})$ & - & $1.60 \times 10^{-8}$ \\
$V_{b i}(V)$ & - & 1.75
\end{tabular}

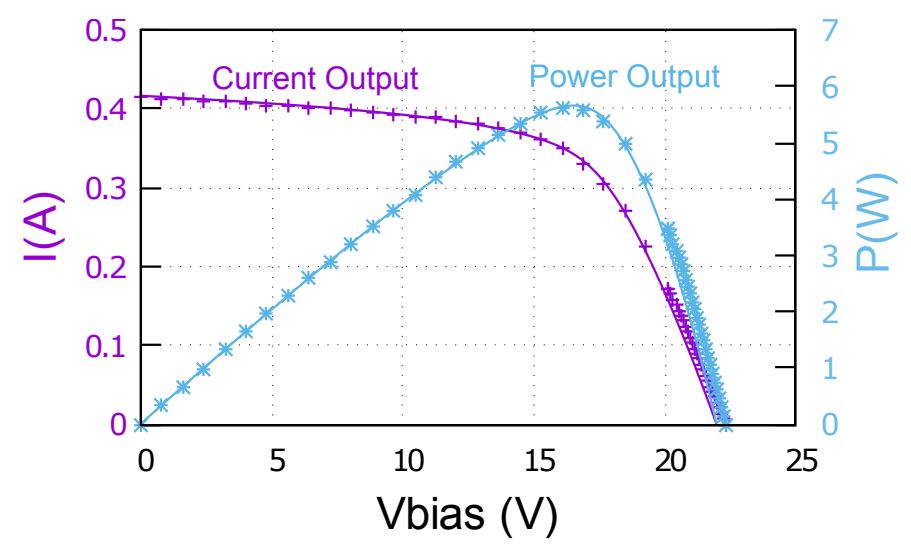

Fig. 9. Calibration of the electrical model example - performed by comparing measured and modelled $I-V$ curves. ( $a$-Si module under concentration, May 17, 2014, 10:39 UTC) 


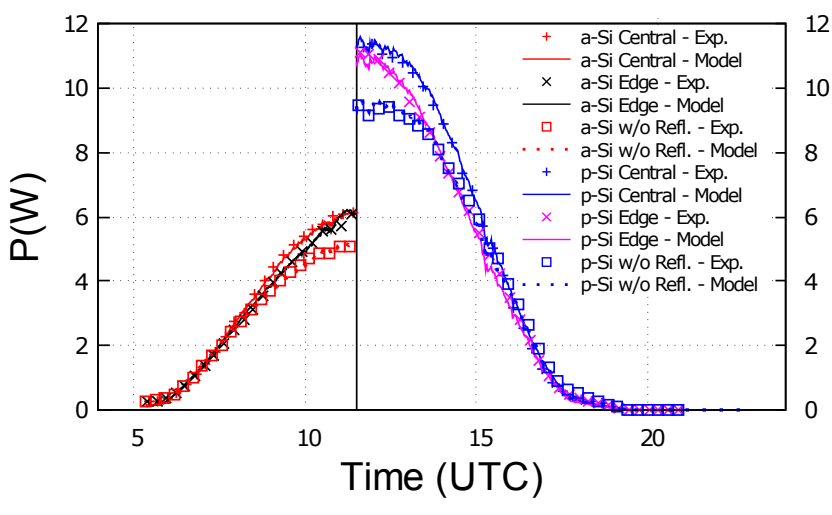

Fig. 10. Integrated model reproducing the maximum power point, $P_{m p p}$, of central and edge modules under concentration, as well as control modules. Power losses due to string mismatches are apparent.

\section{Integrated Model Validation}

The integrated model was run using the measured module temperatures and atmospheric data of May 17, 2014, a relatively clear day, and the results were compared with module power output measurements. As seen in Fig. 10, the power output of 6 modules was simulated: a central, an edge and a control module of both $a$-Si and $p$-Si technologies. The string mismatch effect observable in the performance of edge modules was successfully reproduced, validating the model. On this day, the following gains in produced energy were achieved: $19 \%$ and $16 \%$ for central and edge $a$-Si modules, and $10 \%$ and $6 \%$ for the central and edge $p$-Si modules. This shows the advantage of the amorphous module topology in portrait orientation, with cells extending along the total height of the module.

\section{Example Application}

The model was used to evaluate the influence of the distance of a module from the edge of the row on the yield (see Fig. 11). To emphasize the edge effect, the annual production of east edge modules was considered during morning periods (a similar behaviour exists during evening periods for the west edge modules). During these periods, the influence of the reflector varies based on the distance from the edge, favouring the central modules. Furthermore, as the edge effect and the string mismatch are the most influential during clear sky periods, a clear-sky model [39] was used to set irradiance values.

The result of such a study can be used to decide on the optimal length of a reflector overhang to minimise the edge effect and in turn maximise production (in this case, 2-3 module widths). Note that in temperate climates, where the diffuse component presents a significant portion of the total irradiation, the edge effect will be less influential on the yield.

\section{CONCLUSION}

The experimental data show that the use of fixed planar concentrators is a low-cost technique to increase system yield, resulting in gains in daily produced energy of up to $35 \%$ during clear sky days of certain periods of the year. Gains in monthly

\section{Annual Morning Energy Production (Solar Time $\leq 12$, Clear Sky)}

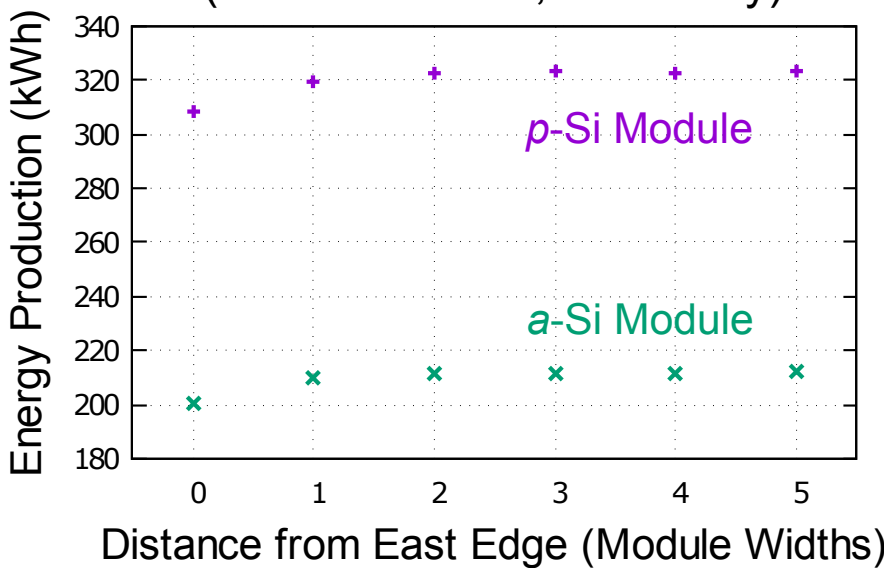

Fig. 11. Annual morning energy production of $a$-Si and $p$-Si modules as a function of distance from the east row edge, evaluated under clear sky conditions [39]. The equivalent energy productions for frontal $a$-Si and $p$-Si modules are $183 \mathrm{kWh}$ and $282 \mathrm{kWh}$, respectively.

produced energy of up to $26 \%$ and $18 \%$ were measured for $a$-Si and $p$-Si modules, respectively.

A multiphysics model was developed to study the performance of a low-concentration PV system, introducing a new modelling methodology to evaluate the impact of the string mismatch on the performance of $a$-Si and $p$-Si modules under various configurations. The string mismatch can have a considerable impact on the performance of reflector-equipped PV modules, and was found to affect $p$-Si modules more severely than $a$-Si modules due to the difference in cell layout. The model can be used to find the system setting that will maximize the system yield.

\section{ACKNOWLEDGMENT}

The authors would like to thank the STARWEST team [29], SOLEMS company and LaSIPS for their kind support.

\section{REFERENCES}

[1] G. E. Ahmad and H. M. S. Hussein, "Comparative study of pv modules with and without a tilted plane reflector," Energy conversion and management, vol. 42, no. 11, p. 13271333, 2001.

[2] R. W. Andrews, A. Pollard, and J. M. Pearce, Model of Loss Mechanisms for Low Optical Concentration on Solar Photovoltaic Arrays with Planar Reflectors. Rayleigh NC, 2011, p. 04460453. [Online]. Available: http://www.academia.edu/1843822/ Model_of_Loss_Mechanisms_for_Low_Optical_Concentratioon_on_ Solar_Photovoltaic_Arrays with_Planar_Reflectors

[3] —, Photovoltaic System Performance Enhancement With NonTracking Planar Concentrators: Experimental Results and BDRF Based Modelling. IEEE, 2013, p. 02290234. [Online]. Available: http://ieeexplore.ieee.org/xpls/abs_all.jsp?arnumber $=6744136$

[4] M. Aziz-ul Huq, M. Hossain, and M. Rahman, Effect of flat reflectors on the performance of photovoltaic modules, 2000, vol. 1, p. 161168 vol.1.

[5] J. W. Bollentin and R. D. Wilk, "Modeling the solar irradiation on flat plate collectors augmented with planar reflectors," Solar Energy, vol. 55, no. 5, p. 343354, Nov 1995.

[6] L. Broman, Non-Imaging Solar Concentrators With Flat Mirrors, 1984 vol. 0441, p. 102109. [Online]. Available: http://dx.doi.org/10.1117/12. 937707 
[7] K.-K. Chong, C.-W. Wong, F.-L. Siaw, and T.-K. Yew, Solar flux distribution analysis of Non-Imaging Planar Concentrator for the application in concentrator photovoltaic system, Jun 2010, p. 003013003018.

[8] M. Garca, L. Marroyo, E. Lorenzo, and M. Prez, "Experimental energy yield in 15 and 2 pv concentrators with conventional modules," Progress in Photovoltaics: Research and Applications, vol. 16, no. 3, p. 261270, May 2008.

[9] S. L. Grassie and N. R. Sheridan, "The use of planar reflectors for increasing the energy yield of flat-plate collectors," Solar Energy, vol. 19 , no. 6, p. 663668, 1977.

[10] D. P. Grimmer, K. G. Zinn, K. C. Herr, and B. E. Wood, "Augmented solar energy collection using different types of planar reflective surfaces; theoretical calculations and experimental results," Solar energy, vol. 21, no. 6, p. 497501, 1978.

[11] H. M. S. Hussein, G. E. Ahmad, and M. A. Mohamad, "Optimization of operational and design parameters of plane reflector-tilted flat plate solar collector systems," Energy, vol. 25, no. 6, p. 529542, Jun 2000.

[12] L. T. Kostic and Z. T. Pavlovic, "Optimal position of flat plate reflectors of solar thermal collector," Energy and Buildings, vol. 45, p. 161168, Feb 2012.

[13] D. C. Larson, "Optimization of flat-plate collector-flat mirror systems," Solar Energy, vol. 24, no. 2, p. 203207, 1980

[14] T. Matsushima, T. Setaka, and S. Muroyama, "Concentrating solar module with horizontal reflectors," Solar energy materials and solar cells, vol. 75, no. 3, p. 603612, 2003.

[15] D. K. McDaniels, D. H. Lowndes, H. Mathew, J. Reynolds, and R. Gray, "Enhanced solar energy collection using reflector-solar thermal collector combinations," Solar Energy, vol. 17, no. 5, p. 277283, Nov 1975.

[16] B. Perers, "Optical modelling of solar collectors and booster reflectors under non stationary conditions: application for collector testing, system simulation and evaluation," Ph.D. dissertation, Uppsala University, 1995.

[17] B. Perers and B. Karlsson, "External reflectors for large solar collector arrays, simulation model and experimental results," Solar Energy, vol. 51, no. 5, p. 327337, 1993.

[18] M. D. J. Pucar and A. R. Despic, "The enhancement of energy gain of solar collectors and photovoltaic panels by the reflection of solar beams," Energy, vol. 27, no. 3, p. 205223, 2002.

[19] F. Reis, M. Brito, V. Corregidor, J. Wemans, and G. Sorasio, "Modeling the performance of low concentration photovoltaic systems," Solar Energy Materials and Solar Cells, vol. 94, no. 7, p. 12221226, Jul 2010.

[20] M. Ronnelid, B. Karlsson, P. Krohn, and J. Wennerberg, "Booster reflectors for pv modules in sweden," Progress in Photovoltaics: Research and Applications, vol. 8, no. 3, p. 279291, May 2000

[21] S. C. Seitel, "Collector performance enhancement with flat reflectors," Solar Energy, vol. 17, no. 5, p. 291295, Nov 1975.

[22] R. Soler-Bientz, F. Gomez-Castro, and L. Omar-Ricalde, Preliminary results of a computational tool to model low concentration PV modules, Jun 2010, p. 002779002784.

[23] H. Tabaei and M. Ameri, "The effect of booster reflectors on the photovoltaic water pumping system performance," Journal of Solar Energy Engineering, vol. 134, no. 1, p. 014501, 2012.

[24] H. Tabor, "Mirror boosters for solar collectors," Solar Energy, vol. 10, no. 3, p. 111118, Jul 1966

[25] H. Tanaka, "Solar thermal collector augmented by flat plate booster reflector: Optimum inclination of collector and reflector," Applied Energy, vol. 88, no. 4, p. 13951404, Apr 2011

[26] J. Wennerberg, J. Kessler, J. Hedstrm, L. Stolt, B. Karlsson, and M. Rnnelid, "Thin film pv modules for low-concentrating systems," Solar Energy, vol. 69, p. 243255, 2001.

[27] R. Winston, J. J. OGallagher, and R. C. Gee, Nonimaging solar concentrator with uniform irradiance, Sep 2004, p. 237239. [Online]. Available: http://apps.webofknowledge.com.accesdistant.upmc.fr/full_ record.do?product=UA\&search_mode=GeneralSearch\&qid=25\&SID= T2IM6D2IVA1JMPMo6BM\&page $=1 \&$ doc $=5$

[28] M. Haeffelin, L. Barthès, O. Bock, C. Boitel, S. Bony, D. Bouniol, H. Chepfer, M. Chiriaco, J. Cuesta, J. Delanoë, and et al., "Sirta, a ground-based atmospheric observatory for cloud and aerosol research," Ann. Geophys., vol. 23, no. 2, p. 253275, Feb 2005.

[29] J. Delatorre, G. Baud, J. J. Bézian, S. Blanco, C. Caliot, J. F. Cornet, C. Coustet, J. Dauchet, M. El Hafi, V. Eymet, and et al., "Monte carlo advances and concentrated solar applications," Solar Energy, vol. 103, p. 653681, May 2014.

[30] P. Hoang, V. Bourdin, Q. Liu, G. Caruso, and V. Archambault, "Coupling optical and thermal models to accurately predict pv panel electricity production," Solar Energy Materials and Solar Cells, vol. 125, p. 325338, Jun 2014
[31] M. N. Polyanskiy, "Refractive index database," 2014. [Online]. Available: http://refractiveindex.info

[32] V. Bourdin, "Master physique et ingénierie de l'energie." [Online]. Available: http://perso.limsi.fr/bourdin/master/Calculs_astronomiques_ simples.pdf

[33] IMCCE, "Ephémérides générales de position des corps du système solaire." [Online]. Available: http://www.imcce.fr/fr/ephemerides/ formulaire/form_ephepos.php

[34] J. A. Duffie and W. A. Beckman, "Solar engineering of thermal processes," NASA STI/Recon Technical Report A, vol. 81, p. 16591, 1980.

[35] H. Hottel and B. Woertz, "Performance of flat-plate solar-heat collectors," Trans. ASME (Am. Soc. Mech. Eng.); (United States), vol. 64, Jan 1942. [Online]. Available: http://www.osti.gov/scitech/ biblio/5052689

[36] J. W. Bishop, "Computer simulation of the effects of electrical mismatches in photovoltaic cell interconnection circuits," Solar Cells, vol. 25 , no. 1 , p. 7389 , Oct 1988 .

[37] S. Silvestre, A. Boronat, and A. Chouder, "Study of bypass diodes configuration on pv modules," Applied Energy, vol. 86, no. 9, p. 16321640, Sep 2009.

[38] J. Merten, J. M. Asensi, C. Voz, A. V. Shah, R. Platz, and J. Andreu, "Improved equivalent circuit and analytical model for amorphous silicon solar cells and modules," Electron Devices, IEEE Transactions on, vol. 45, no. 2, p. 423429, 1998.

[39] M. Lefèvre, A. Oumbe, P. Blanc, B. Espinar, B. Gschwind, Z. Qu, L. Wald, M. Schroedter-Homscheidt, C. Hoyer-Klick, A. Arola, and et al., "Mcclear: a new model estimating downwelling solar radiation at ground level in clear-sky conditions," Atmos. Meas. Tech., vol. 6, no. 9 , p. 24032418, Sep 2013 